\title{
Neoliberalism and social work with children and families in the UK: On-going challenges and critical possibilities
}

Steve Rogowski, Former children and families' social worker, England

\begin{abstract}
INTRODUCTION: Neoliberalism, the belief that free market economies are the best way to achieve human well-being, continues to dominate economic, political and social life in the UK, Europe and the globalised world. In the UK the welfare state has gradually been dismantled and become more punitive, the market place has been introduced, and social work has been deprofessionalised and transformed into a narrower, more restricted, role. Instead of relationshipbased work, practitioners are largely concerned with completing bureaucracy speedily to ration resources and assess/manage risk. Moreover, in relation to children and families, parents need to be self-responsible and, if they fail, a punitive response awaits: being told to change their behaviour/lifestyle or face losing their children to adoption.
\end{abstract}

APPROACH AND CONCLUSIONS: Drawing and building upon my previous work (for example, Rogowski, 2010, 2011, 2013, 2016), this article outlines the neoliberal changes and challenges to social work with children and families in the UK, arguing that critical practice is ever more necessary. Such practice entails working alongside children and families on the issues at the root of social injustice, notably growing inequality in the neoliberalised world. Importantly, examples of what such a practice might entail are highlighted.

KEYWORDS: critical practice; managerialism; neoliberalism; social work with children and families; welfare state

AOTEAROA

NEW ZEALAND SOCIAL WORK 30(3), 72-83.

CORRESPONDENCE TO: Steve Rogowski drbigpike@talktalk.net
Professional social work in the United Kingdom peaked following the establishment of the welfare state during the post-war years of the social democratic consensus (for example, Ferguson, 2008; Garrett, 2009, 2009a; Rogowski, 2010). It was a product of a collectivist era when the state played a key role in ensuring the basic needs of citizens were met in relation to health, housing, education, employment and social security. Eventually Social Services Departments were established whereby social workers helped deal with ongoing social problems by direct work with individuals, families, groups and communities, as well as advocating and co-ordinating the work of other agencies to meet needs. Corresponding with the ideological move to the right and neoliberalism following the election of Margaret Thatcher as Prime Minister in 1979, the situation altered.

The New Right applied classical liberal critiques of state action to contemporary issues of economic and social policy, including preferring market to public sector approaches to welfare (Ferguson, 2008; Garrett, 2009b; Rogowski, 2010). Social workers subsequently felt the brunt of this changed climate. In the late 1980s and 1990s, the introduction of care management 
led to deprofessionalisation concerning work with adults. Social work's decline accelerated during the New Labour years, particularly in relation to practice with children and families. Despite talk of the 'Third Way', Labour largely continued with neoliberalism, a comment which applies to the subsequent Coalition and now Conservative governments. Consequences include the increased privatisation of services, the use of the voluntary or third sector, and social workers being controlled by managers whose emphasis is on completing bureaucracy speedily to meet targets. In short, practice has become de-professionalised and dominated by managerialism and the social work business (Harris, 2003; Harris \& White, 2009), with this escalating under the "alchemy of austerity" (Clarke \& Newman, 2012) which has led to massive cuts to public services.

In what follows, I locate the ideological changes of the last 40 years as being at the root of the challenges to social work in the UK and focus on practice with children and families. However, it is also important to note that the larger themes developed are equally applicable to countries such as New Zealand, Australia, Canada and the USA (see, for example, Beddoe \& Maidment, 2013; Mullaly \& Dupre, forthcoming; Pease, Goldingay, Hosken, \& Nipperess, 2016). First, I comment on the move from social democracy to neoliberalism. Second, I look at how social work has changed under neoliberalism, particularly work with children and families. Third, the effects of this change in relation to deprofessionalisation, managerialism and the social work business are critically discussed. And fourth, despite on-going challenges to critical, indeed radical practice, I outline some ways forward.

\section{From social democracy to neoliberalism}

The social democratic consensus of the initial post-war years resonated across most of the traditional Labour and Conservative party policy remits. This Keynesianism involved agreement on the nationalisation of major industries and planning their development to eliminate the "boom and bust" of capitalism, together with the state needing to intervene to temper the causes of social inequities by creating the welfare state. Social problems that remained were explained by an individual's psychological make-up which was susceptible to diagnosis and treatment by, among others, social workers. Notions of solidarity were premised upon the view that the state could motivate national growth and well-being by the encouragement of social responsibility and the mutuality of social risk (George \& Wilding, 1976).

As Labour and Conservative governments alternated into the 1970s, differences between them amounted to a little more or a little less government ownership and economic planning, with the welfare state rubric being accepted. Within this consensus, social work came of age, particularly as the Seebohm Report (1968) led to local authority Social Services Departments being established to provide community-based, family-oriented services. However, this occurred when the consensus was to fall apart. The seeds of this collapse were laid earlier in the world economic crisis of 1973, and culminated in the election of Thatcher. Monetarism, a forerunner of today's neoliberalism, replaced Keynesianism, which signalled a return to the free market ideology that had been discarded since the 1930s' Great Depression (Ferguson, 2008; Harvey, 2007).

The New Right political movement argued for a complete break with Keynesianism because social democracy, including the welfare state and social work was, for them, a major part of the problem. The rise and now domination of neoliberalism, drawing on the work of Hayek and Friedman, is the result (see O'Brien \& Penna, 1998). This ideology is based on the belief in individual freedom by reducing government regulation in order to liberate individual entrepreneurial skills within an institutional 
framework characterised by strong property rights (Harvey, 2007). Its core idea is that free markets and free trade best achieve human well-being, despite leading to vast increases in inequality along with anxiety and insecurity in the lives of many (Ferguson, 2008; Garrett, 2009b; Rogowski, 2013, 2015, 2016).

The New Right achieved power by employing arguments such as the concept of dependency culture arising from a toogenerous welfare state, militant trade unions holding employers and governments to ransom, and a lack of law and order. This grouping of economic and political interests also sought to reduce state intervention, notably in relation to welfare where selfserving professions such as social work were seen as encouraging welfare dependency. Such views were to lead to the "postwelfarist" or neoliberal state (Harvey, 2007), whereby the quasi-market succeeded bureaucratic institutional structures as the mechanism and legitimating form for the allocation of resources from central state to local providers, and with market competition and logic shaping the value, purpose and practice of provision (Le Grand, 2001). In brief, Social Services Departments were regarded as costly and inefficient with the way forward being seen as an increased emphasis on self-help and individual responsibility, more 'choice' and freedom, and an extension of the commodification of social relations.

Despite Tony Blair's general election victory in 1997, the continuities were with the New Right/neoliberal turn and many of New Labour policies simply "out Toried the Tories" (Powell, 2000, p. 54; also see Powell, 2008) by consolidating and building on the Conservatives' reforms. Social work was drawn deeper into managerial, marketoriented ways of thinking and practising (Harris \& White, 2009). Although the neoliberal project led to the 2007/08 financial crash and resulting Great Recession, it emerged remarkably unscathed, with subsequent governments implementing savage public expenditure cuts and attempts to "get more for less" under the banner of austerity (Farnsworth \& Irving, 2018; McGimpsey, 2017). Such austerity policies are designed to continue the dismantling of the welfare state, bring down wages and fully marketise the economy, thus destroying all the post-war social and economic gains of ordinary people. More positively, however, the Labour Party under Jeremy Corbyn has returned to Old Labour and its more robust social democratic roots which, in turn, has led to a more widespread questioning of the whole neoliberal project.

\section{Social work and neoliberalism}

As indicated, the organisational and practice changes to social work over recent decades need to be understood in terms of neoliberalism and neoliberalisation. Thus, the Thatcher and John Major Conservative governments (1979-1990 and 1990-1997 respectively) over-saw developments which impacted fundamentally on social work. As well as the introduction of the aforementioned care management for work with older people, the need for a social work qualification for probation was ended, and the introduction of the Diploma of Social Work in 1989 allowed employers to shape social work education in their own interests. Importantly, the Children Act 1989, despite its preventative and partnership ethos, confirmed a move from child welfare to child protection (see Parton, 1996 for a discussion of these issues). No longer was child abuse a medico-social problem with doctors and social workers the key professionals; instead it was socio-legal issue, with the police and courts taking an increasing role. Social workers became investigators with parents becoming objects of enquiry; the move was from therapy and welfare to surveillance and control (Howe, 1992).

Then there was social work's 1980s' success in relation to young offending by diversion from the youth justice system and developing alternatives to incarceration (Blagg \& Smith, 1989; Pitts, 1988; Rogowski, 
2016; Thorpe, Smith, Greenwood, \& Paley, 1980). Despite this arguably being the most evidenced-based social work achievement, this was totally ignored as, from 1991 onwards, "populist punitiveness" emerged with politicians of all parties becoming increasingly blaming and punishment orientated in their pronouncements (Bottoms, 1995). The culmination was New Labour's Crime and Disorder Act 1998 which led to social work's role being marginalised as practitioners were merged into Youth Offending Teams with various other professionals.

Under Tony Blair's (and later Gordon Brown's) New Labour governments (19972007 and 2007-2010 respectively) social work fared even worse. For instance, the Care Standards Act 2000 saw the Central Council for the Education and Training in Social Work replaced by the General Social Care Council to regulate social work training and the social work and care workforce. The Social Care Institute for Excellence (SCIE) was also established to identify and disseminate evidence-based practice, with the demise of the National Institute of Social Work (NISW) subsequently occurring. The use of the word care and not social work shows the disdain with which New Labour held social work and their desire to cleanse and remove any oppositional possibilities to the neoliberal project (Garrett, 2009; Rogowski, 2010).

The standardised assessment framework (Department of Health et al., 2000) was also introduced and involved the completion of detailed initial and core assessments via computer exemplars as an attempt to define the indeterminacy, uncertainty and ambiguity in practice by introducing a "techno-rationalist" method (Cleaver \& Walker, 2004). This led to a focus on information gathering at the expense of meeting needs, with processing and classification rather than direct work with children and families dominating. It was an assessment process underpinned by the functional objective to manage risk and police the socially marginalised, and was used to screen out some needs, redefine them as someone else's problem, or say they were insufficiently serious to warrant intervention (Smith, 2008).

New agencies, including statutorily enforced partnerships and quangos were also created, all impacting negatively on social work.

An obvious example is the aforementioned Youth Offending Teams, but there was also social work's absence from any real role in relation to Sure Start and the Children's Fund, preventative initiatives for younger and older children and their families respectively. The absence meant that what used to be the preserve of highly trained professionals, namely social workers, was increasingly carried out by less qualified support, outreach and other staff (Ferguson, 2008; Garrett, 2009; Rogowski, 2010).

Other important developments arose from two high-profile, child abuse tragedies.

First, there was the fall-out from the Victoria Climbie Inquiry (Laming Report, 2003) into the death of a young girl who died of injuries inflicted by her carers. Every Child Matters (Department of Education and Skills, 2004) and the resulting Children Act 2004 aimed to transform children's services and enhance the integration of health, education, social services/care and others; this led to the demise of Social Services Departments and their replacement by Children's Trusts. As a result, practitioners no longer had a safe, supportive base in their own local authority department (Garrett, 2009b; Rogowski, 2010, 2013).

The second tragedy was that of Baby P, Peter Connelly, who died in 2007. Although initially social workers were vilified, in many ways this led to a more progressive debate about social work for children and families which continued into David Cameron's Coalition government of 2010-2015 (Garrett, 2009a; Jones, 2014). For example, following the establishment of the Social Work Task Force (SWTF, 2009) and the Munro Review (Munro, 2011) there was increased public awareness about the short-falls of the 
electronic recording system social workers were forced to use, including the inordinate amount of practitioners' time spent on computers and bureaucracy in general this called into question New Labour's "modernization agenda". Furthermore, a Social Work Reform Board was established to improve social work which included the establishment of a College of Social Work to provide a voice for, and raise the status of, the profession.

However, despite such fine aspirations, the resulting action did not always live up to the expectations of practitioners. Although there was the introduction of a single assessment instead of the initial/core assessments and child protection guidance was reduced, bureaucracy actually increased because of an undue focus on risk with its assessment/ management now being a key component of practice (Rogowski, 2014). Indeed, at a time of austerity, perhaps we should not underestimate the huge challenges to creating the paradigm shift the SWTF and Munro Review aimed to achieve (Parton, 2012). For instance, the College of Social Work soon closed due to lack of funding under the Coalition government's austerity measures.

As for Theresa May's (2015-present) current Conservative government, social work with children and families continues to be on the defensive (see Rogowski, forthcoming). Practitioners still face inordinate amounts of bureaucracy with little time available to work directly with children and families. Unless there are child protection concerns, cases are quickly closed. There is also an increased emphasis on adoption with some local authorities setting targets for how many children should be adopted from care, notwithstanding that there are no targets for the rehabilitation of children home from care. In any case, the setting of such targets is ethically questionable especially when one bears in mind that the right to family life (where it is safe), is a human right enjoyed by both parents and children. In addition, the decision to place a child for adoption should always be a last resort simply because help and support can enable families to stay together, even though austerity policies and cuts to services work against this.

Another cause for concern are plans to shift children's services into independent trusts, this being part of growing movement towards independent provision of children's services which adds to fears about a marketplace in the sector. Meanwhile, families and councils remain on the receiving end of austerity policies: cuts to welfare benefits, housing and support services such as children's centres and youth work, with all of this coupled with flat lining in-work incomes and increasing income insecurity. Overall, expenditure on local authority children's services has been drastically reduced despite rising demand and growing numbers of children; the government narrative largely remains that councils need to do more with less.

The most significant recent piece of legislation has been the Children and Social Work Act, 2017 which provides a new regulator for social work; Social Work England, and attempts to give greater clarity to councils as "corporate parents" of children and young people in care, and care leavers. Fortunately, attempts by ministers to insert "opt-out clauses" in the legislation to give favoured councils exemption from children's social care laws (supposedly to encourage innovation), were dropped. However, concerns remain about politicians taking control of social work, especially as new powers are given to the education secretary to set "improvement standards" for social workers and introduce assessments for practitioners.

\section{De-professionalisation, managerialism and the social work business}

Although professionalism can be attacked from the political left (see Simpkin, 1983) a more enduring attack on professional or "producer power" came from the New Right (George \& Wilding, 1994), this being 
taken up by New Labour arguing public services, including social work, had to become "modernised" and responsible to the "consumer". At a rhetorical level, this meant increased professionalism through the introduction of the social work BA degree although, on the other hand, this pre-occupation functions to ensure a reliable and compliant workforce working at the will of employers through managers (Dominelli, 2009; Ferguson, 2008; Ferguson \& Woodward, 2009). Essentially, the degree focuses on the practical knowledge social workers require (Department of Health, 2002) to the exclusion of the knowledge to be gleaned in order to combat social injustice. Further, despite the emphasis on continuing professional development, the preoccupation with "competence" is an example of it being governmental tool for the regulatory control of professionals (Eraut, 1994).

Under the Coalition and current Tory government, the face of social work education changed further with the introduction of fast-track training programmes like "Step Up to Social Work" and "Frontline". These initiatives have created a two-tier social work education system; a key concern being that the focus of the programmes is on practical knowledge and the skills employers need rather than the theoretical underpinning of a practice which confronts social inequality.

As for managerialism and the social work as business ideology (see for example, Clarke, 1998; Clarke \& Newman, 1997; Evans, 2009; Harris, 2003; Rogowski, 2010, 2011), such developments transformed the way welfare organisations carry out government policy - a change reflecting the move away from administering of public services to their management (Harris \& White, 2009). It stemmed from the neoliberal dogma that the market was superior to the state and that public services needed to be managed much like the private sector. Similarly, the social work business involves the neoliberal view that public services, including social work, had to become more like private firms, functioning in a context as market-like as possible. Importantly, information and communication technologies (ICTs) fulfilled a crucial role in terms of technologising and marketising the public sector (Harris, 2003). Most recently, we have even seen attempts to open up child protection in England to a commercial market place and more privatisation (Jones, 2018).

The need for efficiency, effective targeting, and ensuring that the requirements of "customers" dominate, rather than those of service providers, have been the arguments put forward for businesscentric reform. However, and as alluded to, the poorly conceived introduction of this model meant that social workers had to spend most of their time in-putting data rather than working with children and families (Hall, Peckover, \& White, 2008; White, Wastell, Broadhurst, \& Hall, 2010). Furthermore, despite the rhetoric referring to "empowerment", "choice" and "needs-led assessment", the consequence of the changes for practice have been far-reaching with social work taken "away from approaches that were therapeutic or which stressed the importance of casework, let alone anything more radical or progressive" (Harris, 2003, p. 66). Moreover, the move to the managerial social work business is anathema to social work values and its commitment to social justice and social change.

In a different vein, the changes outlined impacted negatively simply because "practice landscapes under modernising agendas had served to undo good practice" (Doyle \& Kennedy, 2009, p. 51) because they often result in the policing function dominating practice objectives. This is at the expense of other priorities, including the perceived and real needs of users (Stepney, 2006). Practitioners are often so busy at "getting (the current) the job" done that they are in danger of losing sight of what and who they are, including their professional uniqueness and style of intervention; in many cases filling in forms and in-putting data becomes the be-all and end-all. Again, 
it is worth emphasising that the modernising developments lead to practitioners completing assessments within specific timescales with little time spent helping children and families.

Similarly, concerning social work with young offenders, the influence of managerialism is exemplified in forms aimed at assisting decision-making in practice which are merely management tools to improve information gathering (Smith, 2007; Whyte, 2009) and lead to a "zombification" of social workers in youth justice (Pitts, 2001). In short, data in-putting dominates rather than direct work with young offenders and their families on issues of concern.

\section{Critical/radical possibilities}

In many ways, social workers have "been turned into unreflective people-processors by waves of managerialism over the last 30 years and, more recently, by the intertwining of managerialism with New Labour's modernisation agenda" (White, 2009, p. 129). This has remained the case under subsequent governments despite lip service occasionally being given to reducing social work bureaucracy. This is because of the central neoliberal focus on marketisation, reducing public expenditure and, my concern here, controlling social workers and service users. If intervention occurs, it is supposed to be evidence-based but, as stated, in most cases unless there are child protection concerns or a serious risk to oneself or others, little is offered. Interventions that do occur are usually of a controlling, authoritarian nature, amounting to parents being told to change their life-styles or face the consequences of losing their children.

Despite the foregoing, and as I have argued previously (for example, Rogowski, 2010, 2016), there are a range of commentators informed by a critical perspective who manage to retain a sense of optimism. Garrett (for example, 2003, 2009b) focuses on the remaking or transforming of social work with children and families; Ferguson
(2008; Ferguson \& Woodward, 2009) wants to reclaim social work together with reasserting a radical/critical approach (see also Lavalette, 2011; Turbett, 2014); and Jordan (2007, 2008, 2010; see also Jordan \& Drakeford, 2013) looks at re-working the relationship between social work and wellbeing. All these thinkers develop important arguments points and there is merit in repeating some of their key points here.

First, Garrett provides a critical account of the changes afflicting social work with children and families because of neoliberal rationality. However, although neoliberalism is the dominant "common sense" or ideology, it contains flaws and inconsistencies and thus there are opportunities. He refers to Gramsci's notion of "hegemony" with the emphasis on words and discursive struggle being linked to more orthodox politics based on political parties, trade unions, professional associations and social groups; this means it is possible to create counter-hegemonic strategies aimed at social change.

Second, Ferguson voices similar concerns relating to the dominance of neoliberalism, how it has changed social work, the need for the profession to be reclaimed, and why a radical/critical practice still retains its relevance. He notes that bureaucracy, rationing of resources, and increasingly having to be the moral police, all contribute to a profound sense of dissatisfaction among social workers. However, with this dissatisfaction the seeds of resistance are sown, not least in a desire to re-engage with a radical/critical practice which provide social work with "resources for hope" (Batsleer \& Humphries, 2000).

Third, Jordan, never comfortable with the market mentality of neoliberalism, eschews the perspective of accountants, managers and government ministers, re-emphasising social work's concern with relationships and feelings which are not vague, woolly concepts. He argues social work sits well with a happiness and 
well-being agenda which sees a future consisting of environmental awareness, a revival of respect and mutuality among ethnic diversity, and a vision of our collective quality of life.

All three perspectives see social work as far more than the neoliberal preoccupation of being able to deliver services to individuals whose well-being is taken to lie in a choice of alternative suppliers, or as offering interventions to target specific behaviours. Rather practice comprises interactions involving emotions such as empathy, trust and respect; these being the mechanisms which produce much of the value of social work. And in a similar vein is the more recent work of Featherstone and colleagues (Featherstone, Gupta, Morris, \& White, 2018; Featherstone, White, \& Morris, 2014). They criticise a social work model geared to crisis intervention in relation to child protection, instead seeing the value of community social work whereby teams are based in local communities with children and families treated both as individuals and as members of the neighbor-hood. They critique the current practice assumption that the harms children need protecting from are found within individual families and caused by acts of omission/commission by parents or carers. Related assumptions include the belief that such acts are due to attachment issues or poor lifestyle choices; intervention being primarily based on protecting children by identifying what distinguishes this family from others in similar circumstances rather than identifying common challenges to good parenting such as poverty and poor housing; and seeing procedures, risk assessment and multi-agency working as the core to child protection.

Instead, the argument is for a different child protection narrative; one that acknowledges the impact of poverty and inequality on children and families and which interrogates the causes and consequences of deprivation. An obvious point is that there are clear links between deprivation and the rates of children being taken into care. Their social model draws attention to the economic, environmental and cultural barriers to ensuring children are cared for safely. This includes fresh assumptions such as: currently there are inequalities in children's chances of living safely with their families; these inequalities are related to deprivation and other outcomes of inequality such as physical and mental health; and social and collective strategies need to be integrated with humane practices directed at individual families.

The arguments presented here entail a refutation of government claims that they are engaged in an ongoing - improvement of the child protection system. Austerity policies have actually increased the number of children and families in poverty while simultaneously reducing the support available. This, in turn, reinforces the inequalities that limit the potential of growing numbers of children and families, including the abilities of parents/carers to care for children safely.

\section{Practice examples}

When considering the aforementioned, many overburdened practitioners query how such ideas can be applied in day-to-day practice? Nevertheless, I maintain that there are opportunities to challenge rather than simply support the status quo. More emphasis can be placed on the caring side of social work, one which is more compatible with social justice and social change.

Nowadays, critical/radical practice, may have to amount to 'quiet challenges' and resistance to managerial and business orientated discourses and practices (White, 2009), and a number of examples spring to mind. For instance, one can mystify or conceal knowledge of users in order to acquire resources - this amounts to the manipulation of knowledge and information on their behalf. Or again, one could delay or exaggerate paperwork or assessment plans so that managers are manipulated into taking a particular course of action. Ignoring, bending or re-interpreting rules and 
procedures also have a role to play. When it comes to more specific cases, let us look at what a critical/radical practice might entail.

First, disaffected teenagers can be hard to reach and engage with. A social worker could be faced with a 15-year-old young man with a disrupted care background. He might be challenging in relation to not going to school, being disruptive when there and often going missing from home. Drug and alcohol abuse are other issues. He may refuse to engage with social workers because, at the instigation of managers, they keep changing or his case is closed. Faced with this, it is important that the young man's views are fully reflected in the various assessments and other reports, together with the need for practitioners to persevere, be available and be honest and consistent in their dealings with him. Admittedly, this can be a difficult task given managers want to process cases as speedily, and with as little recourse to the public purse, as possible. But attempts can be made and be successful despite the difficulties; this resonates with arguments about re-stating the importance of relationship-based practice (Ruch, Turney, \& Ward, 2010).

A second example is that of a teenage girl who is continually absconding, staying out overnight, sometimes for days at a time. She also associates with other girls who then "hang around" with or are targeted by teenage and older young men who befriend and sexually exploit them. Again, in reports written for child exploitation meetings, instead of focusing on inadequate parenting, in effect blaming often single-parent mothers doing their best in difficult circumstances, the practitioner could advocate for more progressive responses such as a group work with the young woman concerned and her female friends, even though few social workers are currently allowed to use this method (Cooney \& Rogowski, 2017). This could, utilising an empowering model (for example, Mullender \& Ward, 1991; Mullender, Ward, \& Fleming, 2013), focus on the issues and concerns but with an emphasis on the young women learning from each other's experiences. The activities of the young women could be related to current society which, despite changes influenced by feminist thought, is still dominated by men.

In relation to child protection/safe-guarding, despite tragedies such as Victoria Climbie and Baby Peter, often it is too easy for practitioners to fall into the trap of seeing themselves solely as the "hard cops" of the welfare state. This is largely because of the role they have been forced into in the current neoliberal world, often involving merely intrusively asking questions, gathering information and in so doing inspecting families' homes and lifestyles. All too often this is carried out, not with the aim of finding out what help and support is needed to provide reasonable care of the children, but rather with a view to defending the organisation's reputation if things go wrong. It is a defensive, risk-averse practice, one that can be defended rather than one that meets the needs of users. Instead, social workers could work with children and families on the basis that they are potential allies in dealing with the issues under consideration.

In a case of neglect, for instance, you could have children arriving at school late or not at all, often ill-clad and hungry, because their single parent mother is often hung-over from repeated alcohol abuse and has been unable to get up. A neoliberal social work approach would be simply to tell her to change her life-style or face the consequences of child protection procedures and care proceedings. A more critical social work approach, however, would work on the issues of concern in a more collaborative/ partnership-oriented way by listening to, and wherever possible, acting on, the mother's and children's view of the situation. This includes spending time with the family, delving into the reasons for her drinking, her and her children's worries and anxieties and so on. Financial and housing problems, for example, might be factors. Linking the family members with, and if necessary, 
accompanying them to, appropriate local groups and agencies dealing with their particular issues might also be needed. Advocating on behalf of their situation might also be required. All this takes time and could well be frowned upon by managers who merely want to quickly process cases, but nonetheless the resilient practitioner will find ways round this and create some space.

Finally, "old" radical social work concerns with such as politicisation and consciencisation can still play a part. It may be difficult to engage in some of the potentially critical/radical community/ group work initiatives of the past (Ferguson, Iokimidis, \& Lavalette, 2018; Lavalette, 2011; Rogowski, 2010; Turbett, 2014). But, and despite the challenges of postmodernism which challenges the basis of over-arching truths, it is still possible to work with users on an individual basis with the aim of developing an understanding of the underlying causes of the problems and difficulties they face, namely the neoliberal system we currently live in.

As well as practitioners working on an individual basis with users in progressive, critical/radical ways, there is also a role for collective action. This means acting with those such as the British Association of Social Workers to ensure a stronger professional identity, as well as the Social Work Action Network to develop strategies to resist managerialism. Trade unions can, and do, assist in such processes. Broader social groupings also have roles to play, an example being the anti-globalisation movement. This movement is significant because of its ability to bring together disparate groups - trade unionists, environmentalists, peace campaigners, feminists, socialists and many others - to challenge the neoliberal world. It amounts to "unity in diversity" (Leonard, 1997, p.177) and points to some ways forward in challenging neoliberal orthodoxy.

Working individually in one's day-to-day practice, as well as collectively along the lines outlined means social work, albeit in a small way, can work towards a different, more just and equal world, not least because more equal societies are better for everyone (Wilkinson \& Pickett, 2009).

\section{Conclusion}

The welfare state is no longer regarded by neoliberals as aiding social solidarity, instead being a means to provide consumers with tailored, cost-effective services. New Labour embraced the new welfare culture, envisaging a modernised welfare state as having to work with the grain of market imperatives (Page, 2009). Such views have been developed and taken further by subsequent Coalition and Conservative governments.

Until recently, all three major political parties in England, along with most of the governments and the main political parties in the developed (and increasingly the developing) world, accept a consensus which views neoliberalism or (in more overtly Marxist terms), global capitalism, as the only way forward. Despite the Great Recession, the belief in free markets and limited state intervention remains intact to the extent that the very existence of social work as a profession is threatened. The caring and supportive side of state social work does not fit in with the neoliberal ideology which emphasises people having to take responsibility for their own lives, nominally supported by family, friends, local community and voluntary organisations where necessary: Cameron's so-called "Big Society". Perhaps all that can be expected over the coming years is that social workers will become even more the acceptable face of the state in saying that no, or minimal, services can be offered. People will be expected to "stand on their own feet" with social workers only intervening if people become a danger to themselves or others, and then in an authoritarian way. But surely all is not lost in view of the rise of Labour's Jeremy Corbyn and his efforts to return the party to a more robust social democratic approach to the economy and politics. 
Corbyn's rise encourages many to take a more optimistic view of future possibilities for critical social work while also acknowledging the pitfalls (Rogowski, 2010, 2013, 2016, forthcoming). Despite challenges and difficulties, opportunities remain and need to be taken as the practice examples outlined earlier indicate. Working individually in one's own practice with users on a critical, indeed, radical basis, must go hand in hand with acting collectively to ensure there is resistance to the neoliberal world. This involves social workers moving beyond being competent technicians, towards a broader concept of what is professional, namely an acknowledgement that knowledge and understanding are required to challenge current managerial obstacles and practices. This knowledge and understanding points towards the structural connections that penetrate the surface of what social workers encounter daily and involves locating users' difficulties and possible solutions within the wider social context.

In summary, against the official agenda of so-called modernisation and transformation in social work, and despite the intensification of work and the individualisation of users, an element of discretion endures (Harris \& White, 2009). As a result, a niche can be found for some progressive, even critical/ radical, possibilities.

\section{References}

Batsleer, J., \& Humphries, B. (Eds.). (2000). Welfare, exclusion and political agency. London, UK: Routledge.

Beddoe, L., \& Maidment, J. (Eds.). (2013). Social work practice for health and wellbeing: Critical issues. Abingdon, Oxon: Routledge.

Blagg, H., \& Smith, D. (1989). Crime, penal policy and social work. Harlow, UK: Longman.

Bottoms, A. (1995). The philosophy and politics of punishment and sentencing. In C. Clarkson \& R. Morgan (Eds.), The politics of sentencing reform (pp. 17-49). Oxford, UK: Oxford University Press.

Clarke, J. (1998). Thriving on chaos? Managerialism and social welfare. In J. Carter (Ed.), Postmodernity and the fragmentation of welfare (pp. 171-186). London, UK: Routledge.

Clarke, J., \& Newman, J. (1997). The managerial state. London, UK: Sage.

Clarke, J., \& Newman, J. (2012). The alchemy of austerity. Critical Social Policy, 32(3), 299-319.
Cleaver, H., \& Walker, S. (2004). From policy to practice: The implementation of a new framework for social assessment of children and families. Child and Family Social Work, 9, 81-90.

Cooney, L., \& Rogowski, S. (2017). Towards a critical feminist practice with children and families: Child sexual exploitation as an exemplar. Practice: Social Work in Action, 9(2), 137-149.

Department for Education and Skills. (2004). Every Child Matters: Change for children. London, UK: Stationery Office.

Department of Health. (2002). Requirements for social work training. London, UK: Author.

Department of Health and Employment/Home Office. (2000). Framework for the assessment of children in need and their families. London, UK: Stationery Office.

Dominelli, L. (2009). Repositioning social work. In R. Adams, L. Dominelli, \& M. Payne (Eds.), Social work: Themes, issues and critical debates (3rd ed., pp. 13-25). Basingstoke, Hants: Palgrave Macmillan.

Doyle, C., \& Kennedy, S. (2009). Children, young people, their families and carers. In P. Higham (Ed.), Post qualifying social work practice (pp. 49-62). London, UK: Sage.

Eraut, M. (1994). Developing professional knowledge and competence. London, UK: Farmer Press.

Evans, T. (2009). Managing to be professional? Team managers and practitioners in modernised social work. In J. Harris \& V. White (Eds.), Modernising social work: Critical considerations (pp. 145-165). Bristol, UK: Policy Press.

Farnsworth, K., \& Irving, Z. (2018). Austerity: Neoliberal dreams come true? Critical Social Policy, 38(3), 461-481.

Featherstone, B., Gupta, A., Morris, K., \& White, S. (2018). Protecting children: A social model. Bristol, UK: Policy Press.

Featherstone, B., White, S., \& Morris, K. (2014). Re-imagining child protection: Towards humane social work with families. Bristol, UK: Policy Press.

Ferguson, I. (2008). Reclaiming social work: Challenging neo-liberalism, promoting social justice. London, UK: Sage.

Ferguson, I., loakimidis, V., \& Lavalette, M. (2018). Global social work in a political context: Radical perspectives. Bristol, UK: Policy Press.

Ferguson, I., \& Woodward, R. (2009). Radical social work in practice: Making a difference. Bristol, UK: Policy Press.

Garrett, P. M. (2003). Remaking social work with children and families: A critical discussion of the "modernisation" of social care. London, UK: Routledge.

Garrett, P. M. (2009a). The case of Baby P: Opening up spaces for the debate on the "transformation" of children's services? Critical Social Policy, 29(3), 533-547.

Garrett, P. M. (2009). "Transforming” children's services: Social work, neoliberalism and the "modern" world. Maidenhead, Berks: Open University Press.

George, V., \& Wilding, P. (1976). Ideology and social welfare. London, UK: Routledge and Kegan Paul.

George, V., \& Wilding, P. (1994). Welfare and ideology. London, UK: Harvester Wheatsheaf. 
Hall, C., Peckover, S., \& White, S. (2008). How practitioners use ICT in social care work. Community Care, 15 May, 26-27.

Harris, J. (2003). The social work business. London, UK: Routledge.

Harris, J., \& White, V. (Eds.). (2009). Modernising social work: Critical considerations. Bristol, UK: Policy Press.

Harvey, D. (2007). A brief history of neo-liberalism. Oxford UK: Oxford University Press.

Howe, D. (1992). Child abuse and the bureaucratisation of social work. Sociological Review, 40(3), 491-508.

Jones, R. (2014). The story of Baby P: Setting the record straight. Bristol, UK: Policy Press.

Jones, R. (2018). In whose interest? The privatisation of child protection and social work. Bristol, UK: Policy Press.

Jordan, B. (2007). Social work and well-being. Lyme Regis, UK: Russell House.

Jordan, B. (2008). Welfare and well-being: Social value in public policy. Bristol, UK: Policy Press.

Jordan, B. (2010). Why the third way failed: Economics, morality and the origins of the "Big Society". Bristol, UK: Policy Press.

Jordan, B., \& Drakeford, M. (2013). Social work and social policy under austerity. Basingstoke, Hants: Palgrave Macmillan.

Laming Report. (2003). The Victoria Climbié inquiry: Report of an inquiry by Lord Laming. London, UK: Stationery Office.

Lavalette, M. (2011). Radical social work today: Social work at the crossroads. Bristol, UK: Policy Press.

Le Grand, J. (2001). Quasi-markets and Social Policy. In S. P. Osborne (Ed.), Public management: Critical perspectives (pp. 9-22). London, UK: Routledge.

Leonard, P. (1997). Postmodern welfare: Reconstructing an emancipatory project. London, UK: Sage.

McGimpsey, I. (2017). Late neoliberalism: Delineating a policy regime. Critical Social Policy, 37(1), 64-84.

Mullaly, B., \& Dupre, M. (forthcoming). The new structural social work: Ideology, theory and practice (4th ed.). Oxford, UK: Oxford University Press.

Mullender, A., \& Ward, D. (1991). Self-directed groupwork Users taking action for empowerment. London, UK: Whiting and Birch

Mullender, A., Ward, D., \& Fleming, J. (2013). Empowerment in action: Self-directed groupwork. Basingstoke, UK: Palgrave Macmillan.

Munro, E. (2011). The Munro review of child protection: Final report. London, UK: Department of Education.

O'Brien, M., \& Penna, S. (1998). Theorising welfare: Enlightenment and modern society. London, UK: Sage.

Page, R. (2009). Labour governments and the welfare state since 1945. Social policy: Themes, issues and debates (2nd ed., pp. 134-162). Harlow, UK: Pearson Longman.

Parton, N. (Ed.). (1996). Social theory, social change and social work. London, UK: Routledge.

Parton, N. (2012). The Munro review of child protection: An appraisal. Children and Society, 26(2), 150-162.

Pease, B., Goldingay, S., Hosken, N., \& Nipperess, N. (Eds.). (2016). Doing critical social work: Theory in practice. London, UK: Allen and Unwin.

Pitts, J. (1988). The politics of juvenile crime. London, UK: Sage.
Pitts, J. (2001). Korrectional karaoke: New Labour and the "zombification" of youth justice. Youth Justice, 1(2), 3-12.

Powell, M. (2000). New Labour and the third way in the British welfare state: A new and distinctive approach. Critical Social Policy, 20(1), 39-60.

Powell, M. (Ed.). (2008). Modernising the welfare state: The Blair legacy. Bristol, UK: Policy Press.

Rogowski, S. (2010). Social work: The rise and fall of a profession? Bristol, UK: Policy Press.

Rogowski, S. (2011). Social work with children and families: Challenges and possibilities in the neoliberal world. British Journal of Social Work, 42(5), 921-940.

Rogowski, S. (2013). Critical social work with children and families: Theory, context and practice. Bristol, UK: Policy Press.

Rogowski, S. (2014). Critical social work in child protection/ safeguarding: Challenges and (fewer) opportunities. Critical and Radical Social Work: An International Journal, 2(1), 43-58.

Rogowski, S. (2015). Margaret Thatcher's legacy for social work with children and families: critical possibilities? Critical and Radical Social Work: An International Journal, 3(1), 53-65.

Rogowski, S. (2016). Social work with children and families: Reflections of a critical practitioner. London, UK: Routledge.

Rogowski, S. (forthcoming). Social work: The rise and fall of a profession? (2nd Edition) Bristol, UK: Policy Press.

Ruch G., Turney D. and Ward A. Eds. (2010) Relationshipbased social work: Getting to the heart of the matter. London, UK: Jessica Kingsley.

Seebohm Report. (1968). Report of the Committee on Local Authority and Allied Social Services, Cmnd 2703. London, UK: HMSO.

Simpkin, M. (1983). Trapped within welfare. Basingstoke, UK: Macmillan.

Smith, R. (2007). Youth justice: Ideas, policy and practice. Cullompton, UK: Willan.

Smith, R. (2008). Social work with young people. Cambridge, UK: Polity Press.

Stepney, P. (2006). Mission impossible: Critical practice in social work. British Journal of Social Work, 36(8), 1289-1307.

SWTF/Social Work Task Force. (2009). Building a safe, confident future. London, UK: General Social Care Council.

Thorpe, D., Smith, D., Greenwood, C., \& Paley, J. (1980). Out of care: The community support of juvenile offenders. London, UK: Allen and Unwin.

Turbett, C. (2014). Doing radical social work (reshaping social work). Basingstoke, Hants: Palgrave Macmillan.

White, V. (2009). Quiet challenges: Professional practice in modernised social work. In J. Harris \& V. White (Eds.), Modernising social work: Critical considerations. Bristol, UK: Policy Press.

White, S., Wastell, D., Broadhurst, K., \& Hall, C. (2010). When policy o'erleaps itself: The "tragic tale" of the integrated children's system. Critical Social Policy, 30(3), 405-429.

Whyte, B. (2009). Youth justice in practice: Making a difference. Bristol, UK: Policy Press.

Wilkinson, R., \& Pickett, K. (2009). The spirit level: Why more equal societies always do better. London, UK: Penguin. 